Original Research Paper

\title{
Difficulties in Translating Terminological Phrasemes in Economic Print Media from French, Spanish and English into Slovak-a Contrastive Approach
}

\author{
L’udmila Mešková and Janka Kubeková \\ Department of Business Communication in Foreign Languages, \\ Matej Bel University, Banská Bystrica, Slovakia
}

\author{
Article history \\ Received: 07-05-2015 \\ Revised: 23-05-2015 \\ Accepted: 23-05-2015 \\ Corresponding Author: \\ Ludmila Mešková \\ Department of Business \\ Communication in Foreign \\ Languages, Matej Bel University \\ Banská Bystrica, Slovakia \\ Email: ludmila.meskova@umb.sk
}

\begin{abstract}
The aim of this study is to demonstrate that the correct identification, understanding and translating of terminological phrasemes can cause difficulty for students, translators, managers and entrepreneurs. The theoretical framework of this study comprises phraseology, phraseodidactics and one branch of cognitive linguistics construction grammar-which takes into account phrases and not only individual words. Professional economic phrasemes were first compiled on the International Monetary Fund (IMF) glossary web 2014 terminological database. From this database, 126 figurative compound terms were selected in three source languages (Spanish, French and English) and compared with terms in one target language (Slovak).We have primarily focused on the occurrence of these terminological phrasemes in the print media and they have been analysed from the point of view of difficulties which might be caused within the process of translation. Similarities and peculiarities of these terminological phrasemes have been discovered through analysis of the equivalents in the four aforementioned languages and the outcomes of this study also highlight differences regarding intercultural aspects. The acquisition of general phrasemes and in this case terminological phrasemes, is the important part of language skills not only for students of economics, but also for future translators and professional translators.
\end{abstract}

Keywords: Cognitive Approach, Phraseology, Phraseodidactics, Professional Language, Terminological Phrasemes, Translation

\section{Introduction}

The research in this study is focused on phraseology as well as phraseodidactics. Emphasis is currently placed upon cognitive approach in this field. The acquisition of language skills according to the methods of traditional teaching does not correspond with cognitive reality. The traditional categories of languages are considered to be "artificially created", because they do not reflect the processing of language structures on a mental level. Cognitive didactics tries to bridge these differences and in the process of foreign language acquisition represents language as one of the possible products of cognition (Tuhárska, 2010; 2011). Construction grammar, developed in the 1980s by linguists such as Fillmore et al., 1988;
Fillmore and Kay, 1996; Kay and Fillmore, 1999; Lakoff, 1977) is understood as being an orientation of cognitive linguistics, which aims to describe and explain mental linguistic constructions and principles. According to Lakoff (1977), constructions themselves must have meanings. Students learn phrasemes and in this case terminological phrasemes, as units.

Terminological phrasemes are researched in a translational manner, because the acquisition of phrasemes in general is considered to be a very important part of language skills not only for students of economics, but also for translation students and indeed professional translators. This process is supposed to be significant for the enrichment of their vocabulary from the point of view of phraseodidactics. 
It is necessary to mention that the history of phraseodidactics has been researched by González Rey (2012). She distinguishes three stages of development of this discipline, i.e., didactics of phraseology, where didactics is applied to phraseology. Both mother tongue and foreign language teachers are interested in teaching phrases. The second stage is represented by phraseology as a linguistic discipline applied to didactics and phraseologists and paremiologists express interest in this discipline. The third stage is phraseodidactics as an independent sphere of phraseology, which enables teachers and phraseologists to focus on didactics of phraseology which has taken its own place in phraseology. The term phraseodidactics first appeared in 1987 in Germany (Kühn, 1987; Ettinger, 1998). An increasing number of researchers were dealing with phraseodidactics, inter alia Galisson (1984; González Rey, 2005; 2010; 2011; Gréciano, 1984b). Therefore, phraseodidactics originated from language didactics. Foreign language teachers started to become interested in the most vital part of language, i.e., phraseology.

Teachers of foreign business language face various problems at the lexical acquisition level. The most problematic area is that of phrasemes and the purpose of this study is to focus on terminological phrasemes and their translation. They have been researched in three source languages: Spanish, French and English and compared with Slovak (West Slavic language) as the target language. Our long experience as teachers and translators has shown us that the correct understanding and translating of phrasemes causes difficulty for students, future translators, managers and entrepreneurs. Even professional translators face problems when translating terminological phrasemes and they express the necessity of having high quality phraseological dictionaries to do this.

Thus, three source languages (English, French and Spanish) and the target language (Slovak) have been researched. As aforementioned, professional economic phrasemes that were first taken from the terminological database: The International Monetary Fund (IMF) glossary web in 2014, have been focused upon. This database refers to a large glossary of economic and financial terms in English, French, Portuguese, Spanish and Russian. This terminology list contains over 150,000 terms useful to translators working with IMF material. It provides English terms with their equivalents in a number of languages. This list includes words, phrases and institutional titles commonly encountered in IMF documents in areas such as money and banking, public finance, balance of payments and economic growth. Only figurative compound terms were dealt with in this study and a set of 126 figurative compound terms in all four languages was compiled. These terms were then examined and compared and a list of their equivalents in the above mentioned languages were compiled. During the next stage of research, their occurrence in the print media has been researched. The chosen phrasemes are illustrated with examples taken from Spanish newspapers, specifically El País, French newspapers Les Echos, La Tribune and the English weekly magazine The Economist. Trend, the weekly magazine and Hospodárske noviny, the daily newspaper, were used as the representatives of the Slovak print media, which focus on the field of economy. In general, the print media frequently employs phrasemes (general, terminological), a phenomenon that can especially be found in economic and financial journalism. Previous research (Mešková, 1999a) demonstrates this tendency very clearly. Journalists rely on metaphorical linguistic tools more often than authors of business reports and scientific articles. In this way it was concluded that the research of these units would be justified. Newspapers use different language to that of the aforementioned genres.

Before the terminological phrasemes of this research will be analysed, professional language, terminology and phraseology will be dealt with from a general point of view. Finally, terminological phrasemes and their translation will be focused upon.

\section{Professional Language}

Professional texts are related to professional language. According to Lerat (1995), professional language cannot be reduced to mere terminology. It uses terms (specific denominations), including nonlinguistic symbols in speech which mobilize common sources of the given language. Therefore, professional language may be defined as using natural language which takes into consideration professional knowledge while its main function is the transmission of knowledge. Dynamic tendencies are manifested in professional communication.

\section{Terminology}

Wüster, the representative of the so-called Vienna School is considered to be the founder of the general theory of terminology. Thanks to his efforts, terminological works in Western Europe in the thirties acquired a systematic form. Wüster (1975) formulated basic terminological principles and working methods. He primarily focused on the harmonisation and standardisation of professional terms. Several terminological research centers were founded in order to further specialize in this field.

Terminology has recently been increasingly gaining importance due to its interdisciplinary character. Jurčacková (2002) astutely identifies terminology as being an interdisciplinary thematic sphere that focuses on terms that are considered to be the basic units of 
thinking and of knowledge. Terminology defines fundamental principles and attributes of terms. Masár (1992) describes terminology as being a set of appellative means that serve for professional communication and not a science of terms. Cabré (1998) understands terminology as a discipline that studies terms as well as their composition, description, edition and the standardization of terminological units. Such work has resulted in terminographical products, for example professional glossaries, technical dictionaries, etc. The term terminology is used to name the set of the terminological units of specific disciplines or specialized spheres and this approach corresponds with the main focus of this study. Džuganová (2002) states that an increasing number of definitions have been formulated about terminology and term. A term or terminological unit is the name or designation of a concept specific to a subject field. The terminology of a given field includes all means of expressions peculiar to that field: Simple terms, complex terms and terminological phrases (Dubuc, 1997). Blais (1993; Bargot, 1998) define the term in a similar manner.

The research presented in this study only deals with compound terms ("complex" terms according to Dubuc aforementioned) that might be considered to be terminological phrasemes. Before analysing the corpus of terminological phrasemes, the terms phraseology, general phraseme and terminological phraseme will be defined more exactly.

\section{Phraseology}

Professional texts not only contain terminology but phraseology too, both general and terminological. Terminology and phraseology are component parts of professional language. Several significant facts will be mentioned here.

The purpose of this study is not to deal with the development of phraseology. It is generally known that Bally (1921) is considered one of the founders of phraseology, but phraseology as a linguistic discipline was developing in the Soviet Union, Czechoslovakia and Poland during the 1950s. Interest in phraseology grew in France in particular during the 1970s and 1980s. Gross $(1988$; 1990) was one of the representatives of computer linguistics and contributed to the development of research into phraseology in France, but he himself has never used this term. He researched into fixed and free expressions within the framework of lexique-grammaire. It was a systematic formal description of language (including fixed expressions) and its analysis. He followed the transformation theory of Harris $(1952$; 1971), who affirmed that a simple sentence and not just a word is a semantic unit. M. Gross ascertained that in French, there are more fixed expressions than free expressions $(2 / 3)$ for the former as opposed to $(1 / 3)$ for the latter. Gross (1996) dealt with the automatic processing of natural languages, specifically with language fixity which is one of the characteristic features of phrasemes. Gréciano (1983; 1984a) was one of the first French linguists who recognized phraseology as being an independent linguistic discipline. González Rey (2002) deals with the development of French phraseology and theoretical issues in detail. She distinguishes between general phraseology and terminological phraseology (within the framework of general and professional language). Both types comprise the following components: Paremiological, collocational and idiomatic.

Modern Spanish phraseology starts with the phraseological studies of Casares (1950), who worked out the first classification of fixed expressions in Spanish. Zuluaga (1980) presented another classification where he also included paremies and collocations. Corpas Pastor (1996) in particular, Ruiz Gurillo (1997; García-Page Sánchez, 2008) contributed to the development of Spanish phraseology to a large extent. Corpas Pastor (1996) defines phrasemes as being lexical units that are composed of a minimum of two components but they can stretch to a complex sentence and thus she includes proverbs into phraseology. These phrasemes are characterized by a high frequency occurrence of inseparable components such as fixity and semantic delimitation, idiomaticity and potential variants.

\section{Definition of Phrasemes}

There are various definitions of what phrasemes are and only a few will be mentioned here. Gréciano (1993) defines a phraseme as being a unit that fulfills at least two of the three following criteria: Polylexicality, fixity and figurativeness. According to Mel'čuk (2011), phrasemes are multi-lexemic statements which are not free (in the sense of the differentiation between free and fixed expressions). Gross (1996) emphasises fixity, polylexicality, semantic opacity, blockage of the transfomation's properties, no insertion of elements, no actualisation of elements. Anscombre and Mejri (2011) state that the issue of fixity is the most important consideration regarding language studies (the identification of fixed expressions, their reconnaissance and the description of their semantic and combinatory properties). As it can be seen, the authors are not united in defining the phraseme. This research was based on the definition which Gréciano provides.

\section{Definition of Terminological Phrasemes}

The terms terminological phraseme and terminological phraseology are fairly recent. Linguists only started to devote more attention to terminological phrasemes at the beginning of the nineties (Gréciano, 
1993), although the term terminological phraseme was used by the Slovak linguist Kučerová (1980) as early as 1980. The research into the relationships between phrasemes and compound terms was based on polylexicality and fixity. Phrasemes and compound terms that have the nature of fixed expressions seem to be quite similar. Mlacek (1980) points out the differentiating specific signs of phrasemes and compound terms and mentions the mutual penetration of phrasemes into terminology and terms into phraseology, for example in Slovak (bod mrazu-dospiet' do bodu mrazu [freezing point-to reach the dead end]). According to Mlacek (1980), phraseology can be based on the re-evaluation of free and fixed expressions of non-phraseological type and not only free expressions, but also non-terminological fixed expressions can become the subject of terminologisation. Both disciplines are considered to be special spheres, but their units do overlap at some points and they even share certain characteristic features.

The presence of terminological metaphors represents another significant opportunity to research the relationship between terminology and phraseology. This phenomenon is a peripheral sphere in terminology, where terminology overlaps with phraseology and idiomatics. According to Čermák (2007), such French expressions as billet vert (dollar), bulle immobilière (real estate bubble) can be named quasi-phrasemes or quasiidioms. After researching into the overlapping of the main aspects of both disciplines, Čermák (2007) concludes that this phenomenon is very small and only occurs in two aspects, i.e., fixity and nominativeness. Several other authors also devote their attention to terminological phrasemes, for example Mlacek and Ďurčo (1995; Mešková, 1999b; Kubeková, 2010; Strnadová and Škvareninová, 2010; Škvareninová, 2011).

Various definitions of terminological phrasemes can be noticed. Terminological phrasemes (Mešková and Olejárová, 2004) are the combinations of language elements that do not determine a term unequivocally. They are characterised by specific paradigmatic and syntagmatic limits with respect to their structure and function (so-called anomalies) leading to fixity. The semantic opacity of terminological phrasemes can be total or partial. Terminological phrasemes are very often figurative. Rosenbaun Franková (2007) posits that terminological phrasemes comprise a terminological component and one or more non-terminological components, the meaning of which is figurative. Terminological phrasemes differ from general phrasemes: In terminological phrasemes there are terminological components (ex.: Grey market $=$ market is a terminological component). The presence of a terminological element is a distinctive sign of terminological phraseme.

\section{Phraseology and Translation}

Translatology and phraseology are considered to be a young science. Scientific approaches to translations have been developing since the $1970 \mathrm{~s}$. Translatological research pursued various different stages during its history. One of them was the Skopostheorie or skopos theory (Reiß and Vermeer, 1991) according to which a translation is dominated by its skopos which is the Greek word for purpose or function. We can see this approach in the translation of many terminological phrasemes.

The role of the translator has changed throughout the past few decades. The idea of language as being a grammatical system and the register of lexical means is not the most important area any more. Language is now defined as being a tool that functions together with cultural and intercultural competence of the individual. The translator is an intermediary between linguistic and cultural communities (Rakšányová, 2007). The difficulties that translators face while translating into a target language result from the different systems of individual languages and the different cultures of individual nations. Translation demands a cultural transfer and the adjustment of a source text into a target text on a lexical level. Translation not only functions in a linguistic space, but also in a particular cultural space, cultural transfer and thus it obtains a dimension of interculturality. The translators should have a cultural sensibility. They should find cultural conformities, similarities or barriers. Thus, the effectiveness of human communication has been increasing. (Rakšányová, 2007). There are many phrasemes in every language that were clearly formed based on cultural preferences that must be respected (Mogorrón Huerta, 2012). The English terminological phraseme spaghetti bowl/noodle bowl is a good example of this phenomenon. It was translated as a calque into Slovak efekt misy špagiet [effect of the bowl of spaghetti]. It is interesting that the component spaghetti, which is typical of Italian culture, is a loan in English, which evokes a metaphor to express the issues that are not linear, but tangled, i.e., complicated. French and Spanish use a different metaphor of the sense "tangle" maraña de acuerdos/écheveau d'accords (example 12).

It is possible to conclude that all these aforementioned examples involve cultural aspects from the point of view of translation and that is why translation and culture are interconnected (Guidère, 2010).

Many authors agree that translators are required to be multi-professional experts (Gromová and Preložníková, 2007). Because it is not enough for them to only be familiar with one sphere of professional life. Language can be considered as being capital that contributes to the development of economic and 
cultural life (Challe and Logié, 2006). The richness of language is a strategic element and therefore it is important to effectively prepare translators and managers for real-life situations. Translators of professional language need help from professional practice. This fact also causes difficulties for translators.

It is a well-known fact that lexis is the most dynamic stratum of language and it reflects the social changes and needs of its users (Klincková, 2010). When translating terminological phrasemes, we noticed that many of them were formed based on the development of lexis, the need for equivalents in target languages. The impact of other languages on the target language (Slovak) is apparent, which can be proved by loan translations such as calques.

The problem is that the majority of terminological phrasemes are not registered in bilingual dictionaries at all. Bilingual dictionaries do not always include all the information related to current sociocultural aspects, in particular with respect to loan words, neologisms and so on, which might be a problem for translators. We believe that the results of our research will contribute to this area and enrich such dictionaries.

\section{Analysis of Terminological Phrasemes}

This study does not analyse all terminological phrasemes from the field of economy and finance. We primarily devote our attention to those which are frequent in the aforementioned database. A lot of terminological phrasemes from this field have been researched and explained in the previous studies (Mešková and Olejárová, 2004; Mešková, 2007).

Terminological phrasemes in the corpus have been analysed in accordance with their translational equivalents. They have been divided into several groups, depending on whether they are totally identical in the compared languages, partly identical, different, or if the equivalent in the target language and compared languages is the compound term, or a free expression. Several authors deal with the problem of equivalency within the process of translation. Kade (1968) distinguishes four types of equivalency in the professional translation: Total, facultative, approximate and zero. Nida and Taber (1969) maintain that there are two basic types of equivalency: Formal equivalence and dynamic equivalence. Since it is argued dynamic equivalence in translation goes beyond correct communication of information. Jakobson (1959) states that equivalence in difference is the cardinal problem of language as well as the key issue of linguistic. From our point of view it is related to cultural differences of specific nationalities and countries and these differences must be respected. Some phraseologists distinguish between several levels of translational equivalents of phrasemes, such as total, partial and zero equivalency (Corpas Pastor, 2003; Mogorrón Huerta, 2014)

This analysis of terminological phrasemes is based on the works of the two aforementioned linguists. They will be studied based on their translation equivalences: Be it total, partial, zero or completely different. The colour component equivalents will be examined separately. The translation process reveals the existing differences between the source and the target language, both in terms of structure and the eventual culture gap.

\section{Identity of Phraseological Equivalents}

\section{Total Identity of Equivalents}

In the first group, no difference of terminological phrasemes is evident, considering their figurativeness. The same metaphor is observed in all of these expressions in the compared languages (Spanish, French, English, Slovak). However, in the Slovak language (1) the synonym dravé fondy [funds of prey] is used as well. In the square brackets literal translations of Slovak examples are given in order to highlight the difference or the specificity of the metaphor.

(1) fondos buitre/fonds vautour/vulture funds/supie fondy, dravie fondy [vulture funds, funds of prey]

El ministro de Economía apura las negociaciones en el juicio contra los 'fondos buitre'

http://economia.elpais.com

Alors qu'ils attendent toujours d'être remboursés par l'Argentine, les fonds vautours ont une raison de se réjouir: la justice américaine vient de leur donner un droit d'accès à des informations concernant les biens de l'Etat argentin à l'étranger.

http://www.lesechos.fr

Supie fondy vykupujú hypotéky za miliardy. http://hn.hnonline.sk

President Cristina Fernández de Kirchner has always opposed stumping up to the "holdout" creditors-also dubbed vulture funds.

http://www.economist.com

(2) activos tóxicos/actifs toxiques/toxic assets/toxické aktíva [toxic assets]

El Gobierno de Mariano Rajoy parece haber descartado la idea de crear un banco malo con financiación estatal que agrupe los activos tóxicos del ladrillo.

http://economia.elpais.com 
... les provisions pour litiges et les dépréciations sur ses actifs toxiques...

http://www.lesechos.fr

When the American government found itself owning or guaranteeing toxic assets, it turned to Black Rock, which was seen as having more limited conflicts of interest than everyone else concerned, to analyse, value and sell them.

http://www.economist.com

Do nej vloží toxické aktíva, informovala $\mathrm{v}$ utorok večer belgická tlačová agentúra Belga s odvolaním sa na belgického premiéra Yvesa Leterma a ministra financií Didiera Reyndersa http://finweb.hnonline.sk/

(3) préstamo ninja/prêt Ninja (The acronym $N-I-N-J-A$ stands for "No income, no job or assets" and refers to mortgages where the borrower does not have to supply verification of their income, job, or assets)/Ninja loan/Ninja úvery

This terminological phraseme is complicated for translators unless they are given the proper explanation. However, it may rather evoke the hero from a very famous cartoon.

"Washington, D.C.- El 10 de octubre de 2008 tuvo lugar una ceremonia en la que la Corporación Interamericanade Inversiones (CII) firmó un préstamo Ninja de US\$70 millones, sindicado en Japón, con Mizuho Corporate Bank, Ltd. ("Mizuho") New York Branch. http://www.iic.org

Les prêts aux NINJA se sont alors transformés en bombes à retardement. http://archives.lesechos.fr

Išlo predovšetkým o tzv. NINJA úvery a hypotéky. NINJA je slangová banková skratka $v$ angličtine pre No Income Job No Assets, išlo teda o úvery poskytované bez potvrdenia o prijme, zamestnaní či iných aktivitách, ktorými by bolo možné ručit'. http://spravy.pravda.sk

This happened in the US with teaser mortgages, ninja loans and the rest; it ends in disaster.

http://www.economist.com

(4) la mano invisible/main invisible/invisible hand/neviditel'ná ruka (trhu) [invisible hand (of market)]
Asisten impotentes a la mano invisible, que no es tan invisible, que decide sobre la economía real de forma rápida, imprevisible y antidemocrática.

http://elpais.com

... des choix rationnels d'un marché de l'investissement, fut-il guidé par une main invisible aux pouvoirs magiques.

http://www.lesechos.fr

A little help from the invisible hand http://www.economist.com

Myslím si, že ked' nič iné, tak vývoj Slovenska za posledných 20 rokov je toho presvedčivým dôkazom. „Neviditel'ná ruka (trhu)“ ukázala viac, ako viditel’né výsledky http://style.hnonline.sk.

The same imagery can be observed in all of the researched languages and there is a metaphoric transparency in all of these cases. This means that these types of terminological phrasemes are not problematic for translators.

\section{Partial Identity of Equivalents}

In the case of this terminological phraseme (5) there is no difference between the compared Romance languages (Spanish and French). There is the non-fixed expression podradné dlhopisy s vysokou mierou rizika [inferior bonds with high level of risk] in Slovak. On the other hand, the phraseme dinero rápido (6) has the same metaphor in Spanish and Slovak. In English, French and Spanish, the same metaphor in the expressions argent futé, smart money, dinero listo can be detected. In Slovak, the English word smart is a loan word and also has other meanings. For example, it indicates a make of car and a type of phone, too:

(5) bono basura/actifs pourris/junk bonds/podradné dlhopisy s vysokou mierou rizika [inferior bonds with high level of risk] Moody's solo salva del bono basura a siete bancos españoles

http://economia.elpais.com

La bonne solution, ce n'est pas de s'attaquer aux actifs pourris mais aux banques pourries. .. http://www.lesechos.fr

Junk bonds have historically been less sensitive to interest-rate swings than Treasuries or high-grade corporate debt, because their prices are more closely linked to the credit quality of individual issuers. http://www.economist.com 
Rizikové podradné dlhopisy s vysokým úrokom sa vangličtine nazývajú ,junk bonds“(,junk“, po anglicky „odpad“). Tento status sa týka napríklad cenných papierov Mad'arska alebo Grécka. http://www.tyzden.sk

(6) dinero rápido, dinero listo, dinero inteligente/argent futé/smart Money/rýchle peniaze [quick money]

El dinero rápido tiene un precio.

http://elpais.com

Cette définition sous-entend la suggestion d'une raison pour laquelle il est si difficile de profiter de « l'argent futé » en pariant contre des bulles ...

http://www.latribune.fr

For decades, hedge funds have been portrayed as the smart money, with the power to frighten chief executives and destabilise governments; rich individuals and powerful institutions competed to give them money. http://www.economist.com

Rýchle peniaze pre lokálnu ekonomiku http://www.etrend.sk

This group can be problematic from the point of view of translation (example 6).

Identity of Equivalents in the Source Languages, Non-Phraseological Equivalent in the Target Language

On one hand, the same figurative aspect can be observed in French, Spanish and English and on the other hand this is not considered a terminological phraseme in the target language (Slovak), but it belongs to the professional terms:

(7) período de gracia/période de grâce/grace period/prechodné obdobie, obdobie odkladu [transit period, (payment) delay period]

El Gobierno ha apurado hasta el límite los 30 días de periodo de gracia para lograr un acuerdo. http://economia.elpais.com

Samsung vit la fin de sa période de grâce. Le profit opérationnel du géant coréen a plongé de $60 \%$ au $3^{\mathrm{e}}$ trimestre.

http://www.lesechos.fr

If it does not do so by July 30th, when the grace period on a June 30th interest payment to exchange bondholders expires, Argentina will enter into default for the eighth time in its history.

http://www.economist.com

Spracovatel'ské podniky $\mathrm{v}$ potravinárskom priemysle majú do 5. októbra možnost' požiadat' o prechodné obdobie na plnenie niektorých stavebno-technických podmienok podl'a noriem EÚ.

http://hn.hnonline.sk

This group of terminological phrasemes is problematic for translations from Slovak into Spanish, French or English. The elements gracia/grâce/grace have no Slovak equivalent. This could lead to inaccurate translation. Slovak terms such as prechodné obdobie, obdobie odkladu [transit period, (payment) delay period] do not immediately call to mind metaphoric Spanish, French or English terminological phrasemes (periodo de gracia/période de grâce/grace period) In such cases dictionaries are of little help to translators.

\section{Zero Equivalency}

In this group the metaphoric phraseme deuda viva (8) has only been found in the Spanish language, whilst the compound term occurs in the other compared languages:

(8) deuda viva/encours de la dette/outstanding debt/nesplatený dlh [unrepaid debt]

El fondo de rescate bancario y el del pago a proveedores disparan un 39\% la deuda viva. http://economia.elpais.com

L'encours de dette augmente, mais son poids s'allège dans les caisses. de l'Etat!

http://www.lesechos.fr

Few investors would be shocked if Argentina defaults; and its outstanding debt under foreign law amounts to only $\$ 29$ billion, far less than the $\$ 81$ billion it reneged on in 2001 . http://www.economist.com

$\mathrm{Ku}$ koncu minulého roka predstavoval celkový nesplatený dlh v komerčnom realitnom sektore v Európe 970 miliárd eur. http://reality.etrend.sk/komercne

The metaphoric terminological phraseme deuda viva in Spanish is in opposition to the corresponding expressions in the researched languages (compared languages). In French, English and Slovak, there are compound terms (encours de la dette/outstanding debt/nesplateny' dlh [unrepaid debt]. The same 
translatological difficulties could also occur in the group with the partial identity of equivalents.

\section{Different Equivalents}

In the following cases different metaphors have been detected. The Spanish and French languages are different when it comes to regarding their specific metaphors of the terminological phrasemes. It is supposed that the Slovak fixed expression uses the metaphor that is the same in the English language, which is obvious in the case of loan translations (example 9). The Spanish language uses the metaphor of a component colchón [mattress] and French has a less expressive component volant $=$ éventail [fan]. In the expression (10), the Spanish, English and Slovak languages use the same metaphor, whereas the French language uses the metaphor of the snake, but the adjective monétaire replaces the component tunnel. In the example (11) a significant difference in figurativeness is observed. In Spanish and French the same metaphor is applied. However, English is different, while it applies the symbol of the word massage, which substitutes the component maquillage [make up]. No phraseological equivalent exists in Slovak kozmetické úpravy [cosmetic's lifting]:

(9) colchón de capital/volant de capitaux/capital buffer/kapitálový nárazník [capital buffer]

La nueva ley regula los cinco colchones de capital que se podrán exigir a los bancos.

http://economia.elpais.com

Un tel volant de capitaux serait nécessaire pour obtenir un ratio de fonds propres durs (Core Tier 1) de 8\%, a déclaré ce lundi Dirk Jäger, responsable de la supervision et des normes comptables à la Fédération allemande des banques privées (BdB).

http://www.lesechos.fr

The European Commission has proposed compelling money funds to have a predefined capital buffer.

http://www.economist.com

... globálne dozorné orgány požadujú, aby mali finančné ústavy vyššie a kvalitnejšie kapitálové nárazníky.

http://www.finance.sk

(10) serpiente en el túnel/serpent monétaire/snake in the tunnel/had $v$ tuneli [snake in the tunnel]

Durante los últimos siete días la serpiente europea se ha visto sometida a fuertes presiones por el marcado incremento de la demanda del marco alemán, lo que ha producido considerables descensos del dólar. http://elpais.com

Dans l'immédiat, la France pourrait proposer une voie pour y arriver. ... les pays européens décidèrent, avec le Serpent monétaire européen, ...

http://www.lesechos.fr

Undeterred, Europe soon introduced a system to tie currencies to the D-mark, dubbed the "snake in the tunnel".

http://www.economist.com

$\mathrm{V}$ boji s volatilitou menových kurzov po rozpade Brettonwoodského menového systému bol vytvorený tzv. had v tuneli.

http://finweb.hnonline.sk

(11) maquillaje de las cifras/maquillage des chiffres/massage the numbers/kozmetické úpravy [cosmetic's lifting]

Antes de hablar de dudas y maquillajes de las cifras es necesario distinguir entre los conceptos contables de caja, cuando se comparan los ingresos recaudados y gastos pagados, y el criterio de devengo, que cuantifica e incluye los derechos de cobro y las obligaciones de pago, criterio que es el utilizado en Contabilidad Nacional y en las normas europeas.

http://economia.elpais.com

Bernard Accoyer (UMP): "Il y a un maquillage des chiffres sur le chômage" ... Julien Dray, vice-président PS de la région Ile-de-France, était ...

http://www.videos.lesechos.fr

This is not a subtle attempt to massage the numbers.

http://www.economist.com

Nemecko si vynútilo kozmetické úpravy správy OECD

http://hn.hnonline.sk

(12) maraña de acuerdos/écheveau d'accords/spaghetti bowl effect/efekt misky spagiet [effect of the bowl of spaghetti]

This terminological phraseme is the most figurative in English language. In Spanish and French, there is an idea of tangled mess: 
Sin embargo, actividades aparentemente cotidianas para muchos de los actores, requieren de una diversidad de acuerdos y tratados, coordinaciones $\quad \mathrm{y}$ complementariedades de los países, que aún con la maraña de acuerdos que hay en América Latina no tenemos del todo solucionadas. http://www.economiacritica.com

...et surtout dans les effets que cet écheveau d'accords peut avoir sur les petits pays [...] www.fondation-res-publica.org

The spaghetti bowl effect refers to a problem of Free Trade Agreements (FTAs) with rules of origin that designate which country a product comes from.

http://english.caixin.com

Množstvo rôznych dohôd (tzv. „misa špagiet") spôsobuje zvyšovanie nákladov transakcií pre národné hospodárstva a podniky, pretože musia dodržiavat' značne odlišné súbory pravidiel.

www.europarl.europa.eu

Because certain corresponding phrasemes in the researched languages are different, this also leads to a difference in the imagery that they communicate. These differences can indeed complicate the process of translation.

\section{Equivalents with Colour Component}

Terminological phrasemes in which one of the components is expressed by a colour, form a specific group. The symbolism of colours is quite often similar in the compared languages and their cultures, since it does not always coincide. Although the total equivalency is evident, they have been registered in this group:

(13) cisne negro/cygne noir/black swan /čierna labut' [black swan] (Black Swan is an event or occurrence that deviates beyond what is normally expected of a situation and that would be extremely difficult to predict. This term was popularized by Nassim Nicholas Taleb, a finance professor and former Wall Street trader. http://www.investopedia.com/terms/b/blackswa n.asp)

This term is the same in all of the researched languages. It is a loan translation. The term black swan is also applied in the case of 11 September 2001:

Nassim Taleb [matemático y financiero libanés] escribió sobre la teoría del cisne negro, que está siempre a la vuelta de la esquina.

http://economia.elpais.com/economia/2014/06 /19/actualidad/1403190330 584111.html

Investisseurs, un nouveau catalyseur de leur crainte obsessionnelle d'un cygne noir.... http://lesechospedia.lesechos.fr

Teória čiernej labute, ktorá vysvetl'uje, prečo vznikajú burzové krachy a prečo môžu mat' ovel'a ničivejšiu silu ako by ktokol'vek čakal. http://finweb.hnonline.sk

This was not a black swan or a fat tail, it was betting on something everyone knew was a bubble and taking so much leverage on this bet that when the bubble popped insolvency was assured.

http://www.economist.com

The black colour (Mollard-Desfour, 2005) has a positive connotation, (in English and Slovak), especially in the field of accounting, as the profit in financial records is written in black, because the black colour represents profit in financial records. To be in the black/être dans le vert/byt' $v$ čiernych čislach, byt' $v$ pluse [to be in the black numbers/to be in plus]. In the Slovak language the expression to be in plus is much more common. In this case, the French language uses the colour green, which indicates the positive financial result of a company.

Another case of a positive connotation might be seen in the expressions such as Viernes Negro/Vendredi Noir/Black Friday (In the United States, the day after Thanksgiving. Black Friday is considered the first day of the Christmas shopping season each year. It is noted for discounts and special offers on retail goods)/čierny piatok. But on the other hand, this colour can have a negative connotation, for example Black Monday (Refers to October 19, 1987, when the Dow Jones Industrial Average fell 508 points on the heels of sharp drops the previous week. On Monday, October 27, 1997, the Dow dropped 554 points. While the point drop set a new record, the percentage decline was substantially less than in 1987)/lunes negro/lundi noir/čierny pondelok [Black Monday]:

(14) zona gris/zone grise/grey area/šedá zona [grey zone]

Es más, hay claros indicios de que Berlín y sus aliados impondrán duras condiciones si el Gobierno de Rajoy sale de la zona gris en la que se ha atrincherado y solicita una ayuda que parece inevitable.

http://internacional.elpais.com 
Après l'annexion de la Crimée par la Fédération de Russie, le maître du Kremlin est sur le point de créer une enclave prorusse dans les régions sud-est de son voisin, hors de contrôle de Kiev depuis l'échec de l'opération militaire visant à enrayer la poussée séparatiste téléguidée par Moscou. Cette nouvelle zone grise en pleine Europe, similaire à la région russophone de Transnistrie en Moldavie, a des contours géographiques flous.

http://www.lesechos.fr

Šedá zóna existuje $\mathrm{z}$ hl'adiska právnej regulácie, z hl'adiska reálneho fungovania systému, ale aj z hl'adiska vzt'ahov medzi nimi. http://blog.etrend.sk

An international grey area

http://www.economist.com

(15) brotes verdes/pousses vertes/green shoots/zelené výhonky, prvé výhonky, prvé náznaky [green shoots, first shoots, first signs]

Green is considered to be the colour of peace, hope, etc. This symbology is also applied in the phraseme green shoots, which is used in the field of economy to indicate the first signs of the economic upturn in the period of the economy in decline. The Slovak equivalent zelené výhonky [green shoots] is the loan translation which is used very rarely. Equivalents prvé výhonky, prvé náznaky [first shoots, first signs] have occurred more frequently to indicate an economic recovery:

La fragilidad de los brotes verdes, se les llame como se les llame, es otra de las enseñanzas repetitivas de esta crisis.

http://economia.elpais.com

Indicateurs avancés et "pousses vertes": Un peu d'humour dans un monde où la mesure est la règle

http://archives.lesechos.fr

Ceux qui guettent les fameuses pousses vertes (" green shots ») annonçant une sortie de crise prochaine aux Etats-Unis seront sans doute refroidis par les chiffres du chômage publiés hier.

http://www.lesechos.fr

Ben Bernanke, the Federal Reserve chairman, said on CBS's "60 Minutes" that he is seeing "green shoots" showing up in the economic landscape, "as some confidence begins to come back."

http://roomfordebate.blogs.nytimes.com
Ked' teraz zvädli zelené výhonky zotavenia, rozprúdila sa debata o fiškálnom stimule $\mathrm{s}$ ešte väčšou intenzitou.

http://komentare.hnonline.sk

The research shows that there is a wide range of phrasemes designating colour, such as gray market/mercado gris/marché gris/šedý trh; gray economy/economía gris/économie grise/šedá ekonomika; black money/dinero negro/argent noir/čierne peniaze; black economy/economía negraléconomie noire/čierna ekonomika; black market/mercado negro/marché noir/čierny trh.

In general, these terminological phrasemes do not cause any serious problems within the process of translation and that is why this study does not consider them in any great detail. However, when the symbolism of colours is not the same in the researched languages, it can be difficult to find a relevant equivalent in Slovak (e.g., French terminological phraseme être dans le vert $=b y t^{\prime}$ $v$ čiernych čislach [to be in the black numbers]. French uses the colour green which has a positive connotation in this language, whereas Slovak opts for the colour black which also has a positive connotation. The usage of colours in different languages is not the same and this aspect poses a definite challenge for translators.

\section{Conclusion}

This research demonstrates terminological phrasemes of three source languages (English, French and Spanish) and their translation into one target language (which is Slovak in this case). In order to understand the correct use of terminological phrasemes between them. The vocabulary of terminological phrasemes is also enriched by means of neologisms. In most cases, calques appear in all four of these compared languages, usually from English (compare for example cisne negro/cygne noir/black swan/čierna labut' [black swan]), that are not very problematic for translators. According to the authors Mlacek et al. (2009), phrasemes in Slovak are mostly formed from loans and calques from other languages, which our research proves. In many cases, translators should pay attention to different understandings of various phenomena in individual cultures. For example, there are differences resulting from positive and negative connotation with respect to black and red colours. In some cases, the metaphoric component of these terminological phrasemes is different. It is not always easy for Slovak translators to find an adequate equivalent. Here, cultural differences manifest themselves.

It might be concluded that the same imagery is manifested in the researched Romance languages 
(Spanish, French) in many cases. English often had different expressions to the researched Romance languages. Most of the free expressions and calques that we researched occurred in Slovak.

In our opinion and with respect to teaching professional language (students of economics or translatology), more attention should be paid to the acquisition of terminological phrasemes and phrasemes in general. The cognitive approach of teaching contributes to developing the skills and competencies of students in this area. Students, future translators and professional translators should always consider the target language culture when translating. We come to the conclusion that translators should always employ a creative approach. The creativity in finding solutions to these linguistic challenges in different languages is what makes the work of translators interesting and rewarding.

\section{Author's Contributions}

Both authors equally contributed to this work.

\section{Ethics}

This article is original and contains unpublished material. The corresponding author confirms that all of the other authors have read and approved the manuscript and no ethical issues involved.

\section{References}

IMF, 2014. International Monetary Fund, IMF Terminology. A Multilingual Directory, IMF Glossary Web. https://www.imf.org/external/np/ term /esl/pdf/glossarys.pdf (Accessed on September 25, 2011)

Anscombre, J.C. and S. Mejri, 2011. Le figement ling uistique: La Parole entravée. 1st Edn., Honoré Champion, ISBN-10: 2745321870.

Bally, C., 1921. Traité de stylistique française. Heidelberg.

Bargot, N., 1998. Langage de spécialité et construction de thesaurus. Revue Française de Linguistique Appliqué, 3: 71-97.

Blais, E., 1993. Le phraséologisme. Une hypothèse de travail. Terminologies nouvelles 10.

Cabré, M.T., 1999. Terminology: Theory, Methods and Applications. 1st Edn., John Benjamins Publishing, Amsterdam ISBN-10: 9027216347, pp: 247.

Casares, J., 1950. Introducción a la lexicografía moderna. 1st Edn., Revista de Filología Española, Madrid.

Corpas Pastor, G., 1996. Manual de fraseología española. 1st Edn., Gredos, Madrid, ISBN-13: 9788424918293, pp: 337.
Corpas Pastor, G., 2003. Diez años de Investigación en fraseología: Análisis sintáctico-semánticos, contrastivos y traductológicos. Vervuert, Madrid, ISBN-10: 84-8489-088-0, pp: 326.

Čermák, F., 2007. Frazeologie a idiomatika česká a obecná. 1st Edn., Karolínum, Praha, ISBN-10: 9788024613710, pp: 718.

Dubuc, R., 1997. Terminology: A Practical Approach, adapted by Elaine Kennedy. Quebec, Linguatech, ISBN-10: 978-2-920342-30-9, pp: 196.

Džuganová, B., 2002. Terminológia ako vedná disciplína. Kultúra slova, 36: 129-139. http://arl4.library.sk/arl-sllk/sk/detail-sllk_un_cat0094999-Terminologia-ako-vedna-disciplina/

Ettinger, S., 1998. Einige Überlegungen zur Phraseodidaktik. En: Europhras 95: Europäische Phraseologie im Vergleich: Gemeinsames erbe und kulturelle Vielfalt (Studien zur Phraseologie und parömiologie, 15), Eismann, W. (Ed.), Universitätservlag Dr. N. Brockmeyer, Bochum, ISBN-10: 3-8196-0567-3, pp: 201-217.

Fillmore, C. J., P. Kay and M. C. O'Connor, 1988. Regularity and idiomaticity in grammatical constructions: The case of let alone. Language, 64: 501-538. http://www.jstor.org/discover/10.2307/414531?uid= 2\&uid=4\&sid $=21106420654861$

Fillmore, C. J. and P. Kay, 1996. Construction Grammar. University of California at Berkeley, Department of linguistics.

Galisson, R., 1984. Les Expressions Imagées. 1st Edn., Clé International, Paris, pp: 64.

García-Page Sánchez, M., 2008. Introducción a la fraseología española: Estudio de las locuciones. 1st Edn., Anthropos, Barcelona, ISBN-13: 9788476588673, pp: 527.

González Rey, I., 2002. La Phraséologie du français. 1st Edn., Universitaires du Mirail, Toulouse, ISBN-10: 2858165858, pp: 268.

González Rey, M.I., 2005. L'espace réservé à la phraséologie dans la didactique du F.L.E. En: Espacio y Texto en la Cultura Francesa. Espace et Texte dans la Culture Française, Tomo III, El espacio en la lingüística y la traducción francesas, Ramos, Á.S. (Ed.), Universidad de Alicante, Alicante, ISBN-10: 84-7908-791, pp: 1421-1439.

González Rey, M.I., 2010. La Phraséodidactique en action: Les expressions figées comme objet d'enseignement, La Clé des Langues. 1st Edn., ENS LSH/DGESCO, Lyon.

González Rey, M.I., 2011. La Phraséodidactique du français, un siècle de vie: De Charles Bally à aujourd'hui. En: Multi-lingual Phraseography: Translation and Learning Applications. Bertrán, A.P., L.L. Nadal y J.M.P. Bretaña (Eds.), Schneider Verlag, Baltmannsweiler, ISBN-10: 9783834009470. 
González Rey, M.I., 2012. De la didáctica de la fraseología a la fraseodidáctica. Paremia, 21: 67-84. http://dialnet.unirioja.es/servlet/articulo? $\operatorname{codigo}=443$ 4556

Gréciano, G., 1983. L'irréductibilité de L'expression idiomatique vivante sa paraphrase: Indice de la pluralité de ses dimensions sémantiques et de l'appel, une étude pragmatique de son contenu. Recherches Linguistiques X, Paris.

Gréciano, G., 1984a. A propos de la délimitation de l'idiome. Verbum, 1: 63-79.

Gréciano, G., 1984b. Pour un apprentissage des unités phraséologiques. Nouveaux Cahiers d'Allemand, 2: 95-113.

Gréciano, G., 1993. Vers une modélisation phraséologique: Acquis et projets d'EUROPHRAS. Terminol. Nouvelles, 10: 16-22.

Gromová, E. and S. Preložníková, 2007. Prítomnost' a budúcnost' vyučovania prekladu v kontexte meniaceho sa trhu práce. Preklad a kultúra 2.

Gross, G., 1996. Les Expressions figées en français: noms composés et autres locutions. 1st Edn., Ophrys, Paris, ISBN: 2708007890, pp: 161.

Gross, M., 1988. Les limites de la phrase figée. Langages 90: 7-22.

Gross, M., 1990. Sur la notion harissienne de transformation et son application au francais. Langages, 99: 39-56.

Guidère, M., 2010. Introduction à la traductologie. 2nd Edn., De Boeck, Bruxelles, ISBN-10: 9782804130589, pp: 176.

Harris, Z.S., 1952. Discourse Analysis. 1st Edn., The Waverly Press, Baltimore.

Harris, Z.S., 1971. Structures Mathématiques du Language. 1st Edn., C. Fuchs, Dunod, Paris, ISSN10: 11684364, pp: 248.

Challe, O. and B. Logié, 2006. Marques françaises et langage. 1st Edn., Economica, Paris, ISBN10: $2717851925, \mathrm{pp}: 138$.

Jakobson, R., 1959. On Linguistic Aspects of Translation. R. A. Brower (ed.), On Translation. Cambridge Mass.: Harvard University Press. 232239.

Jurčacková, Z., 2002. Terminológia: Základné zásady, metódy a ich aplikácia. 1st Edn., Centrum vedecko-technických informácií SR, ISBN-10: 8085165856, pp: 72.

Kade, O., 1968. Zufall und Gesetzmäßigkeit in der Übersetzung. 1st Edn., VEB Enzyklopädie, Leipzig, ISBN-10: 174399330, pp: 128.

Kay, P. and C. J. Fillmore, 1999. Grammatical constructions and linguistic generalizations. The what's X doing Y? Construction. Language, 75: 1-33. http://eric.ed.gov/?id=ej586021
Klincková, J., 2010. Konkurencia a kooperácia lexikálnych prostriedkov v profesijnej komunikácii. 1st Edn., Veda vydavatel'stvo SAV, Bratislava, ISBN-10: 9788022411073

Kubeková, J., 2010. Frazeológia v ekonomických periodikách. PhD Thesis, Univerzita Komenského, Bratislava, Slovakia.

Kučerová, E., 1980. Niekol'ko poznámok k preložitel'nosti/nepreložitel'nosti frazeologických jednotiek. Bratislava, ISSN-10: 0448-9241.

Kühn, P., 1987. Deutsch als Fremds prache im phraseodidaktischen

Dornröschenschlaf. Vorschläge für eine Neukonzeption phraseodidaktischer Hilfsmittel. Fremdsprachen Lehren und Lernen, 16: 62-79.

Lakoff, G., 1977. Linguistic Gestalts. Proceedings of the 13th Regional Meeting, Chicago Linguistic Society, Apr. 14-16, Chicago Linguistic Society, University of Chicago, Chicago, Illinois, pp: 236-287.

Lerat, P., 1995. Les langues spécialisées. 1st Edn., Presses Universitaires de France, Paris, ISBN-10: 2130466028, pp: 208

Masár, I., 1992. Systémovost' ako integrálna vlastnost' terminológie. Kultúra slova, 26: 129-138.

Mel'čuk, I., 2011. Tout ce que nous voulions savoir sur les phrasèmes, mais... Observatoire de linguistique Sens-Texte, Université de Montréal.

Mešková, L., 1999a. Deux langues différentes-deux structures différentes? Théorie linguistique et applications informatiques. Actes du $16^{\mathrm{e}}$ Colloque européen sur la grammaire et le lexique compares, Sept. 24-27, Peeters, Louvain-la-Neuve, pp: 133-142.

Mešková, L'. and M. Olejárová, 2004. Les Phrasèmes spécialisés du domaine de la finance. Phraseologie und Parömiologie band 15, Phraseologismen als Gegenstand sprach-und kulturwissenschaftlicher Forschung. Baltmannsweiler Schneider Verlag Hohengehren, ISBN-10: 3896768808, pp: 335.

Mešková, L., 1999b. La Phraséologie et la terminologie dans les textes économiques. Acta linguistica 3, Ekonomická fakulta UMB, Banská Bystrica, ISBN10: 8080553327, pp: 58.

Mešková, L., 2007. Les aspects phraséologiques de la terminonologie en marketing. In: Langue, discours et société. Allemagne, Autriche, Pays-Bas, 5-6. Langue, économie, entreprise, le travail des mots. Presses Sorbonne Nouvelle, Paris, ISBN-10: 9782878543834, pp: 475-484.

Mlacek, J., D. Baláková and V. Kováčová, 2009. Vývin súčasnej frazeológie: východiská, podoby, uplatňovanie, akceptácia. Ružomberok. ISBN: 9788080845193, pp. 221. 
Mlacek, J. and P. Ďurčo, 1995. Frazeologická terminológia. [Phraseological terminology.] Bratislava: Stimul 1995. http://www.juls.savba.sk/ediela/frazeologicka_terminol ogia/

Mlacek, J., 1980. Frazeológia a terminológia. Jazykovedné štúdie 15, Horeckého zborník. J. Ružička. Bratislava, Veda, ISSN-10: 04489241, pp: 181-187.

Mogorrón Huerta, P., 2012. La traduction des unités phraséologiques à contenu culturel, Rencontres Méditerranéennes 4, Langues spécialisées, figement et traduction, P. Mogorrón Huerta, S. Mejri, (Eds.), Quinta Impresión, S. L., ISBN-10: 9788497172097, pp: 81-95.

Mogorrón Huerta, P., 2014. Locuciones verbales, traducción y perdida de equivalencia. In: Fraseología y paremiología: enfonques y applicaciones, Biblioteca Fraseológica y Paremiológica, Madrid, ISBN-10: 9788469703205 , pp. 79-96.

Mollard-Desfour, A., 2005. Le Noir. Dictionnaire de la couleur. Mots et expressions d'aujourd'hui (XXeXXIe). CNRS Éditions, ISBN: 978-2-271-06321-2, pp. 288.

Nida, E. A. and J. Taber, 1969. The Theory and Practice of Translation. E. J. BRILL, Leiden. ISBN: 9004038574, pp. 220.

Rakšányová, J., 2007. Kol'ko kultúry potrebuje odborný prekladatel'. Preklad a kultúra 2, Gromová, E. and Müglová, D., (Eds.), ISBN: 9788080942335, pp.79-97.

Reiß, K. and H. Vermeer, 1991. Grundlegung einer allgemeinen Translationstheorie. Max Niemeyer Verlag: Tübingen.
Rosenbaun Franková, L., 2007. Expressions figées dans un texte de spécialité. Acta Linguistica, 7, vol. 1, Ekonomická fakulta Univerzita Mateja Bela, Banská Bystrica, pp: 224-232.

Ruiz Gurillo, L. 1997. Aspectos de fraseología teórica española. Valencia. ISBN: 8437033276, pp. 92

Strnadová, P. and D. Škvareninová, 2010. Lingvistické aspekty prekladu odborných frazeologizmov $\mathrm{V}$ ekonomickej oblasti. Od textu k prekladu V, Praha, ISBN: 9788073740914, pp: 157-162.

Škvareninová, D., 2011. Niekol'ko poznámok k obraznosti terminologických pomenovaní v odbornom jazyku. Od textu k prekladu IV, Praha, ISBN: 9788073740924, pp: 149-157.

Tuhárska, Z. 2010. Sémantické a kognitívne aspekty skúmania didakticky zameraného odborného textu z oblasti biológie. Banská Bystrica: Univerzita Mateja Bela v Banskej Bystrici. ISBN: 978-80-5570048-9, pp: 60.

Tuhárska, Z. 2011. Die Analyse der semantischkognitiven Ebene der Fachsprache. Untersucht am Beispiel von Texten aus der Biologie. Hamburg: Verlag Dr. Kovač. ISBN-10: 978-3-8300-5444-3, pp: 235.

Wüster, E., 1975. Einführung in die allgemeine Terminologielehre und terminologische Lexikographie. 3. Auflage 1991. Romanistischer Verlag, Bonn. ISBN: 389913401X.

Zuluaga, A., 1980. Introducción al estudio de las expresiones fijas. Studia Romanica et lingüística, 10, P.D. Lang, ISBN: 9783820464405, pp: 278. 